\title{
The Influence of Political Advertisements on Voter's Intention in Pakistan
}

\author{
* Faisal Aziz, PhD Scholar (Corresponding Author)
}

\begin{abstract}
Pakistani media Advertising has gotten more compelling and persuasive in the field of Political correspondence. This research work elaborates the insight about political ads on the democratic expectation of Pakistani electors during the general elections of 2018. The universe for the investigation is the 200 male and female enrolled electors of Sargodha Zone. This paper likewise investigates and analyses the impact of emotional standards, singular mentality, and sentiments toward Political Advertising. There are two medium selected Electronics medium and social media. Selected Electronics Media channels to access political advertising are Geo News, Dunya News, and Express-News although selected Social media Sites are Facebook, YouTube, and Twitter. The data was gathered through well designed quantitative using survey technique. According to the results, the impact was being estimated and it seemed that there is a positive correlation between political Adson elector's goals. The apparatus for the quantitative methodology would be a poll for gathering the information. In the investigation, there are two Variables, political Advertising is the independent variable, and citizens' aim is the dependent variable. Political Advertising is a type of battling utilized by the political possibility to reach and impact electors. The democratic expectation alludes to the mentality, conviction, and estimation of the elector's considerations.
\end{abstract}

Keywords: Political Advertisements, Voters' Intention, Electronic Media, Social Media, Exposure and Impact

\section{Introduction}

Mass Communications in the popularity based structure is viewed as a significant factor in deciding and reinforcing the responsibility and supportability of the public authority. The media assumed a significant function in such a manner, and the discussions offered on the political decision day turned into a significant stage for ideological groups to advance political philosophy (Zahid, 2017). It additionally furnishes blotters with the occasion to get political data and investigate the projects and records that ideological groups and up-and-comers have raised and dispersed during the political race. In the current conditions, the media establishments are viewed as the fourth mainstay of the nation and assume a significant job, particularly in the region of popularity based development. Mass communications are utilized to give joins between governments, ideological groups, applicants, and electors (Valenzuela, et al, 2012). Political investigators have pronounced the 1970 decisions as the main free and reasonable with a shocking difficulty for the more established ideological groups as Pakistan Individuals' Gathering drove by Zulfiqar Ali Bhutto in the West Pakistan and Awami Alliance drove by Mujeeb-ur-Rehman in East Pakistan picked up a larger part situates. The awfulness of East Pakistan was the fate of ensuing significance as the majority rule government accepted force in West Pakistan (Munir, 2011). The PPP government figured the 1973 constitution which was embraced by all standard ideological groups of Pakistan. In the wake of finishing his required residency Mr. Bhutto declared decisions to date for common and public congregations to be hung on Walk 7 and 10, 1977, individually.

Mass Communications don't just pass on data as per the wishes and goals of government officials. Electronic Media and web-based media are utilized to cover quick political occasions and different exercises. It is typically accepted that the public, legislators, and media are self-subordinate yet it's simply the supposition. The public authority influences the media through its buying capacity and the various weights they use to accomplish and advance their political objectives (Highfield, 2017). Mass communications impact the conduct of government authorities by spreading out and legitimizing issues and affecting the general population and citizens by giving them political data. The political framework, political foundation, state society, and conflict are factors that influence the

* Faculty of Media \& Communication Studies, University of Central Punjab, Lahore, Pakistan Email: faysalfifty@gmail.com 
gatherings to define strategies and relating Advertising. This positive affirmation is true, they are a structure, yet an ideological group influence (Bucy, \& Gregson, 2001).

\section{Political Advertising}

Political advertising is characterized as a correspondence circle by which a source purchases an occasion to uncover the objective populace through Mass Channels to Political perspectives, convictions, and practices (Johnson-Cartee, et al., 1997). Political advertising also remembers all types of Advertising for the request to offer help for every political mission, including the possibility for an office, discretionary measures, political activism, and so on Advertising is organized and not close to home correspondence created, by and large paid and regularly convincing in nature, about items by distinguishing supports through various media. Political advertising is organized and made non-individual correspondence, normally paid for and generally convincing in nature, about items by distinguished patrons through different mediums (Wilson, 1995).

The essential thought of a political advertisement rotates around a similar definition it is paid, enticing however as opposed to advancing a certain item it advances a thought. Majority of the researchers consent to the way that Political Advertising which is having a reinforced interpretive strength works best (Jhally, 2014). Electronic Advertising becomes the first method for correspondence by the gatherings to convince irresolute electors and to ensure that they turn up and vote in support of themselves on the election-day. The political decision framework has been changing since autonomy. Subsequently, the political arrangement of Pakistan is still in its exploratory stage. Political conduct is a focal piece of governmental issues of any political framework. A legislative issue is an action identified with the political framework. It isn't just a piece of political life yet public activity as well (Burton, Miller, \& Shea, 2015).

Studies aligned with casting a ballot conduct report that electors can be grouped into seven most significant sorts by their motivation to cast a ballot: Gathering Faithful, Ethical quality looking for Citizens, ally looking for Citizens, Enactment Disapproved of Electors, and advance looking for Electors, Biradari Bound, and doubter Electors. Voting choices are the main choices that the public makes, they conclude who will control the nation and how the assets and capital are distributed. Citizens don't have the foggiest idea about the entirety of the issues. They just transfer on enlightening prompts. Segment factors do impact democratic choices like sexual orientation, race is a higher priority than financial variables like training (Sundquist, 2011).In the most recent couple of years, the ethnic and racial effect on casting ballot choices was concentrated more than different issues. Race and identity had an incredible impact on casting ballot conduct. Social class plays a critical significance in casting ballot conduct. Be that as it may, different variables are indicating a consistently expanding significance today, for example, social class, party approaches, and identity and district issues (Calmore, 2000). Deciding in favor of an applicant's race may be a result of prejudice, or it could be the consequence of dependence on a straightforward, promptly accessible signal. At the end of the day, citizens may uphold an applicant's race or identity dependent on the presumption that a competitor who shares their racial or ethnic foundation additionally shares their essential political perspectives (Ansell, 2013).

\section{Selected Sites of Social Media}

In this research study, three social media sites are selected to show the impact and exposure to political advertising. These sites are Facebook, Twitter, and YouTube. In the electronic media category, the selected news channels are Geo News, Express-News, and Dunya News.

\section{Objectives of the Study}

The followings are the main objectives of this research.

1. To study the effects of exposure to political advertising using social media and Electronics media.

2. To study the effects of political advertising on respondents voting behavior.

3. To explore to what extent understanding of respondents about political advertising of mainstream political parties of Pakistan during general elections of 2018.

4. To document respondents' information consumption patterns about political advertising. 


\section{Hypotheses of this Research Study}

1. It is more likely that respondents gain more political knowledge about political parties through political advertising.

2. It is more likely that social media is more popular then electronics media for political advertising among respondents

3. It is more likely that excessive exposure to political advertisements leaves a significant impact on the voting behavior of voters.

\section{Literature Review}

Media campaigning for political activation through political advertisement. It has been discovered that old-style investigations of decision are the most suitable technique for building up a political strategy. Numerous political business analysts accept that personal circumstances alone, don't rouse citizens to partake in decisions. The sound monetary factor clarifies the impact of media crusades on politically dynamic residents who don't have solid sectarian demeanors uncertain citizens (Stieglitz, \& DangXuan, 2013). The excess citizens are of two sorts; that structure their inclinations based on social or different affiliations, come in any case while electors basically keep away from putting together their choices concerning momentary. Media weight will focus on the unsure electors, who don't have profound feelings while this weight could be work through consistent messages of both direct methods like first-level suppositions and circuitous second level hints. The impact of the media will increment as the size of this gathering increments (Marcus, et. al.2000).

The program, first introduced by Lippmann, alludes to how we structure the pictures in our psyches. Dalton and Wattenberg (1993) speak to another idea regarding this inquiry what guarantees that citizens relate to their appointment of the gathering since they see the objectives of the gathering are viable with their own piece of the electorate. The dynamic cycle just avalanche work wins in the 1997 and 2001 general Elections from one very much prepared media crusade. The work cooperation traversed the most progressive methods of crusading and the making of vital media, picture upgrade, and logical inconsistencies of electors' apprehensions about winning work. It is conceivable to contend that this isn't the situation allies of this feeling contend that abstention may equally affect all the contending parties. Hence, there is no general effect on extortion conduct as a rule; nonetheless, this explanation might be not exactly such a case, stifling turnout by methods for negative battling may support a particular gathering/applicant. There are a small bunch of special cases, the first is an enormous, randomized controlled preliminary (Gates Jr, et. al., 1996).

Eleven months before the 2006 gubernatorial political decision in Texas, the creators arbitrarily chose the circumstance of an advertisement crusade across 18 media markets. From the beginning of time, government officials have utilized different strategies, for example, whistle-stop talks, political Advertising, and political conventions, to accomplish their essential objective, the triumphant of citizens (McEnteer, 2006). Nonetheless, throughout the long term, government officials have discovered that it is generally worthwhile to utilize political advertising to convince electors. Thusly, for a few ongoing political Elections, the significance of political Advertising, particularly on $\mathrm{TV}$, has been expanding, and this reality has been reflected in the drastically expanding Advertising spending plans of ideological groups. Crusade spending in the US grew fifteen-crease since 1952 from $\$ 140$ million to almost $\$ 2$ billion every 1988. Under 5 percent of mission uses in 1952 was given to Radio and TV Time, though in any event $40 \%$ of mission dollars were spent on media consumptions in 1988.

\section{The Impact of Political Advertisements on the Attitude of Voters}

Depending on a board of sense studies; the proof demonstrates a sizeable however passing effect on constituents' mentalities. Comparative with the benchmark group, electors who got crusade messages about the civic chairman's valence refreshed their convictions and expanded their help by about 4.1 rates. The impact was more modest than the message was providers through mass mailings than by telephone, or when it contained data about the civic chairman's philosophy, we study genuine vote shares. Spurred by the US experience, notwithstanding, our attention is on TV advertisements and their amount. The truth of the matter is, in legislative issues, advert crusades have become a basic device utilized for a candidate for different situations to get the electorate to decide in favor of them (Margolis, et al, 2000). Throughout the most recent couple of many years, political Advertising has changed fundamentally. Political Advertising is the fundamental component in political missions, delivering party machines and grass-root and bates in 1992 so sure, not at all like political missions 
previously have progressed in media innovation smoothed out the cycle, giving applicants more alternatives to arrive at the bigger gatherings of constituents with little exertion (Davies, \& Newman, 2006).

\section{Political Communication}

The press and Mass Media assume a huge part in political correspondence. They are by the idea of their working and job, utilize various methods of mediation in legislative issues. The implications of legislative issues are imparted to us through culturists as story systems and to be told as reports. These systems and stories help citizens to take constituent choices. Comparative, ideological groups do distinctive mission channels to get their messages to the electors. Channel depends on the expected of the legislators while their pace of reach and viability shift in various cases (Nimmo, \& Combs, 1992). The examination uncovers the function of Mass Communications in mentalities and social changes, and some contend that it contrasts from the Mass Communications channel, while others contend that the impacts may differ as indicated by segment qualities. An examination of the connection between media use and political information infers that there is a reasonable and positive connection between the recurrence of public help for political substance from Mass communications and the quantity of political information. The mission alludes not exclusively to the detailing and usage of the media procedure during the constituent time frame yet, also, a significant piece of political correspondence which is an unpredictable cycle of political socialization, ideological groups, and the media as a source of political socialization (Spicer, 2013). The spending for advertising significantly expanded for the 2004 Election, both the conservative and progressive alliances spent around \$160 Million on Advertising with expanding the all-out financial plan of political advertising and these advertisements followed a pattern of pessimism. Since political advertising, not at all like item advertising, must get brings about a brief timeframe. Political professionals utilize a few sorts of political advertising, picture, issue, and negative advertising. even though there exists no standard in utilizing political advertising, preceding the 1980s competitors generally utilized issue or picture advertising toward the start of a mission to build up their positive picture and afterward utilized negative advertisements toward the finish of the mission to assault the rival (Seidman, 2008). In any case, those techniques were deserted during the 1980s, huge pattern in the present political Advertising is that an expanding number of applicants, either challengers or officeholders, utilize negative advertising from the earliest starting point of a political mission.

An investigation led by Sabato, (1980) mirrored this pattern in the wake of inspecting more than 1,100 political ads. In any event, when the TV is utilized to impart political truth, reality can be contrarily bundled assaulting the rival's character and record as opposed to supporting one's own. On the off chance that there is a solitary pattern evident to most American specialists, it is the expanding extent of negative political advertising. At any rate, $33 \%$ of all spot ads in ongoing efforts have been negative, and in a minority of missions, half or a greater amount of the spots are negative in tone or substance (Sabato, 1980, p165).

\section{Methodology}

This research work was proposed to assess the Political Advertisements \& Voters Intention during the phase of general elections of 2018 in Pakistan. This research work uses a qualitative method of research methodology. The universe of the current assessment was the Sargodha zone. The universe is included with both Urban and Rural zones. The universe also consists equally of male and female registered voters of the Sargodha Zone. Particular of the respondents are further attributes in the shape of age, and area. Keeping the necessity of the research work data was collected from 200 respondents, 100 male, and 100 female who are enlisted citizens and registered voters from the selected zone. From the Urban and Sub-Urban zone of Sargodha, 100 males and 100 females are carefully selected. In the age response category, there were two categories which belong to up to 22 years and above 22 years. Data was carefully collected through a well-designed questionnaire which was designed according to the need and accessibility of the researcher. The research instrument was translated into the Urdu language. After the division of the respondents into the referenced layers, the utilization of convenience strategy was applied to gather the information from the target respondents. The reliability of the questionnaire was also tested through SPSS 19.0 and the result of the Alpha reliability was above 0.843 which indicates the reliability of the questionnaire. 


\section{Results}

Figure 1. Demographic Distribution of Sample

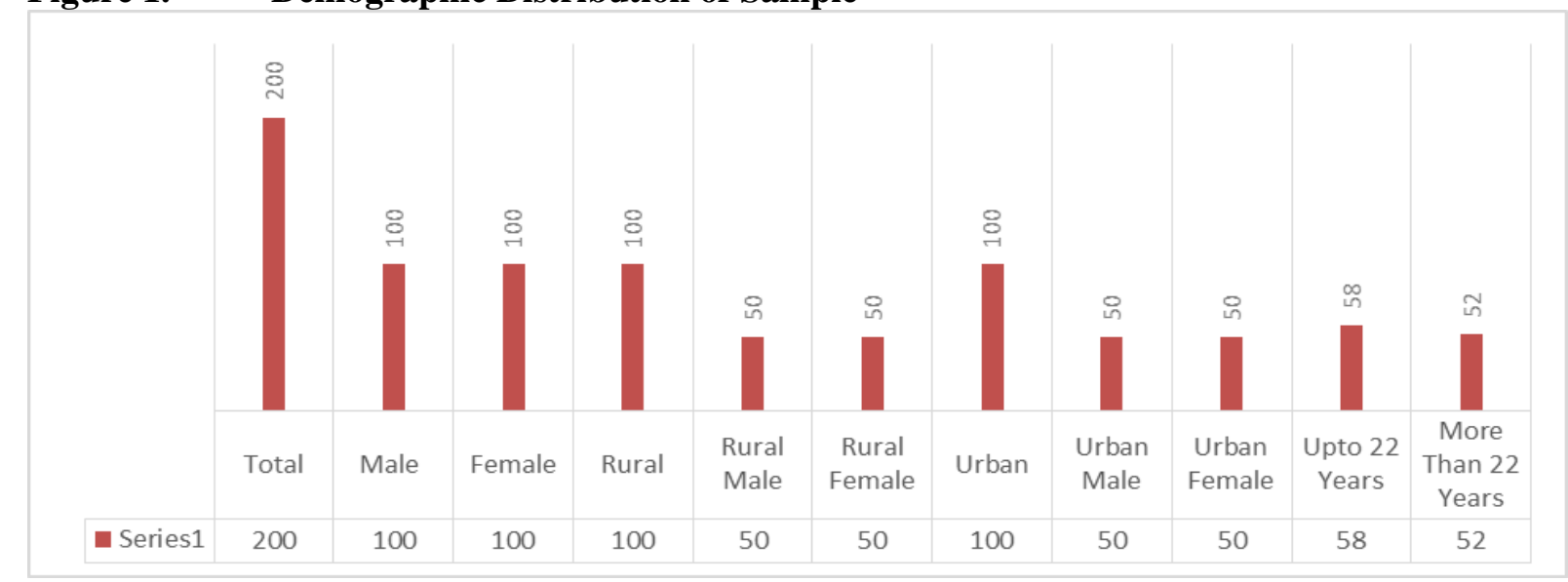

In this research study, the demographic is as shown in the figure. A total of 200 respondents are selected from the Sargodha zone where the area is distributed into two zones like urban zone and the rural zone. In every zone, 50 male and 50 female respondents are carefully selected who are registered voters of and having NADRA CNIC and are eligible for the voting process. The sex of respondents is also distributed equally. 50 male and 50 female respondents are equally selected from both zones. In the age category, there is a slight difference shown after the collection of research data. There were two categories in this regard. One is up-to 22 years age response category and the other is more than 22 age response category.

Table 1. Time spending of respondents on Social media and Electronic Media during a day

\begin{tabular}{llllllll}
\hline & Results & \multicolumn{2}{l}{ Gender } & Age & \multicolumn{3}{c}{ Area } \\
\hline & Overall & A & B & C & D & E & F \\
30 minutes to 1 hours & 32.4 & 33.1 & 31.3 & 38.5 & 26.3 & 37.8 & 26.9 \\
1-2 hours & 23.7 & 22.7 & 25.2 & 28.8 & 18.6 & 20.5 & 26.9 \\
2-3 hours & 26.0 & 22.7 & 30.5 & 24.4 & 27.6 & 24.4 & 27.6 \\
More than 4 hours & 17.9 & 21.5 & 13.0 & $8.3 \%$ & 27.6 & 17.3 & 18.6 \\
$* *$ values shows in percentage (\%) & & & & & & & \\
\hline
\end{tabular}

\section{Legends:}

$\mathrm{A}=$ Male, $\mathrm{B}=$ Female, $\mathrm{C}=\mathrm{Up}$ to 22 years, $\mathrm{D}=$ More than 22 years, $\mathrm{E}=$ Rural, $\mathrm{F}=$ Urban

The above table explores the results of the time spending on respondents who are using social media and electronic media during a day. The empirical results show that there are four response categories in the table which is mentioned above. The first category is 30 minutes to 1-hour consumption pattern during a day. The second response category is from 1-2 hours a day, the third response category is 2-3 hours during a day and the fourth response category is more than 4 hours using social media and electronic media during a day. Legends are explained in alphabetic from A to E. In the gender response category, there is a slight difference in the male and female response categories. In the first category of 30 to 1 hours-time spending, there is a little difference between male and female respondents here (32.4\%) male and (33.1\%) female are using social and electronic media. It is also observed that in the second response category which 1-2 hours is-time spending on social media and electronics media during a day. The respondents of males and females are also a light difference, empirical results show that (33.7\%) males are using social media and electronic media followed by female response category which is $(32.7 \%)$. In the third response, the category males are spending more time on social media and electronic media as compared to female respondents. Here the results show that (26\%) males are time-consuming 2-3 hours daily as compare to $(22.7 \%)$ females which seems a huge difference. In the last category of time spent on social media and electronic media, the results are very different. Here male respondents are spending less time compared to female respondents. $(21.5 \%)$ females are spending time on social media and electronic media as compared to male respondents who are empirical seemed as (17.9\%). The second demographic response category is age. This category is further divided into two response categories. One is up to 22 years and the second is more than 22 hours. The study results show that (31.3\%) up 
to 22 year age respondents and $(26.3 \%)$ are those who are more than 22 years age category are using time 30 minutes to 1 hour during a day. In the second response category $(28.8 \%)$ respondents who belong to the age category up to 22 years and $(18.6 \%)$ respondents more than 22 years are using social media and Electronics Media. In the third response category, there is a little difference $(27.6 \%)$ respondents are those who belong to more than 22 year age response category are using more media as compared to $(24.4 \%)$ respondents who belong to age category up to 22 years. In the fourth and final response category, more than 22 years of age category are heavy users $(27.6 \%)$ as compare to respondents who fall in the category of up to 22 years $(8.3 \%)$. The third demographic distribution is an area. This response category is further divided into two response categories. One is Rural Area and the other is an urban area. (37.8\%) respondents from rural areas are using social media and electronic media followed by $(26.9 \%)$ respondents who belong to an urban area. In the second response category $(20.5 \%)$ rural respondents are spending time 1-2 hours daily as compare to the second response category $(26.9 \%)$. In the third response category of 2-3 hours, time consumption pattern, (24.4\%) rural respondents are spending time followed by (27.6\%) of urban respondents. In the last response category, urban are respondents are higher time spender $(18.6 \%)$ as compare to $(17.6 \%)$ rural respondents who belong to the Sargodha region.

\section{Figure 2. $\quad$ Exposure to Political Advertising during General Election of 2018}

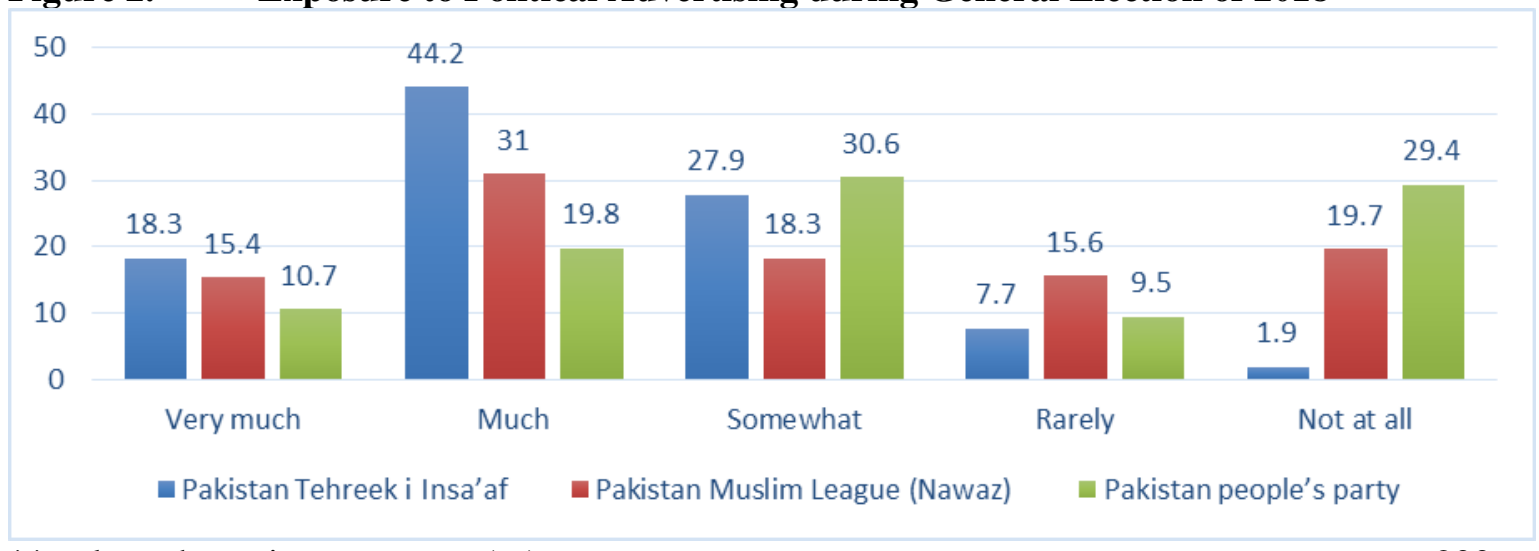

** values shows in percentage (\%) $\mathrm{n}=200$

Above mention, Graph explores the exposure to political advertising during the general elections of 2018. Overall $(18.3 \%)$ respondents responded as very much where $(44.2 \%)$ responded as much followed by (35.6\%) as somewhat and a very little number of respondents who responded as somewhat and not at All. In the second party category which is Pakistan Muslim League (Nawaz) above $(46 \%)$ respondents responded as very much and much response category although $(18.3 \%)$ respondents gave their feedback as somewhat category followed by $(15.6 \%)$ as rarely and $(19.7 \%)$ as Not at All. In the third response category which is related to Pakistan People's Party, the empirical results show that collectively $(40 \%)$ respondents showed their likeness in favor of the very much and much response category. (30.6\%) responded as rarely where above (40\%) responded as not at all. Figure 3 Association between Political Advertising and Political behavior of Voter

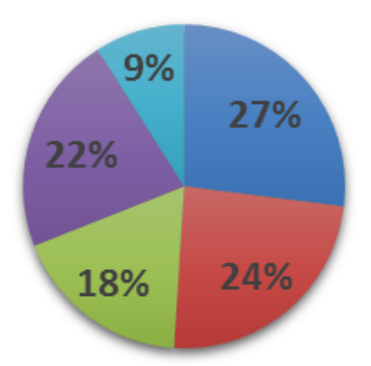

Strongly Agree $\quad$ Agree $\square$ Disagree $\square$ Strongly Disagree $\quad$ Not At All

The above mention graph reveals the empirical results of the association between political advertising and the political behavior of respondents. (27\%) of overall respondents responded as strongly agree with this notion whereas ( $24 \%$ ) answered as agree to this notion. In the third response 
category (18\%) answered as disagreeing and (22\%) replied as strongly disagree followed by a little respond category who answered as not at all.

\section{Research Hypothesis and their Results}

\section{Co-relation}

Co-relation is used to measure the strength and intensity of a relationship between two or more variables. To check intensity between two variables Co-relation is analyzed to check the relationship between variables.

\section{Table 2. Partial Pearson Co-relation}

\begin{tabular}{|c|c|c|c|c|c|}
\hline \multicolumn{3}{|c|}{ Control Variables } & \multirow{2}{*}{$\begin{array}{c}\text { Area } \\
-.039\end{array}$} & \multirow{2}{*}{$\begin{array}{l}\text { Age } \\
.021\end{array}$} & \multirow{2}{*}{$\begin{array}{l}\text { Sex } \\
-.089\end{array}$} \\
\hline $\mathrm{X} 5, \mathrm{X} 6 \ldots \mathrm{X} 55$ & Sex & Co-relation & & & \\
\hline & & Significance (2-tailed) & .499 & .707 & .129 \\
\hline & Age & Co-relation & & -.029 & .103 \\
\hline & & Significance (2-tailed) & . & .701 & .096 \\
\hline & Area & Co-relation & & & -.028 \\
\hline & & Significance (2-tailed) & & . & .671 \\
\hline
\end{tabular}

** Correlation is significant at 0.05 level,

$(\mathrm{n}=200$

A statistical test has been conducted by the researcher to check the intensity of the relationship between variables. After conducting the "Pearson Co-relation test", there is a Very significant Co-relation between the independent and dependent variables. Between age and gender, there was a negative relationship which is $\gamma=-.039$ although the two-tailed relationship between age and gender is Very significant. Furthermore, it is observed that there is a strong positive correlation between variables and $\mathrm{p}$ is $<.499$. In gender and area, there is also a very strong negative relationship here $\gamma=-.028$ and the $p$-value is $<.707$ which is statistically very significant.

\begin{tabular}{|c|c|c|c|c|}
\hline S No & & Hypothesis & Conclusive & Inconclusive \\
\hline 1 & $\mathrm{H}_{1}$ & $\begin{array}{l}\text { It is more likely that respondents gain more political } \\
\text { knowledge about political parties through political } \\
\text { advertising. }\end{array}$ & $\checkmark$ & $\mathrm{X}$ \\
\hline 2 & $\mathrm{H}_{2}$ & $\begin{array}{l}\text { It is more likely that social media is more popular then } \\
\text { electronics media for political advertising among } \\
\text { respondents }\end{array}$ & $\checkmark$ & $X$ \\
\hline 3 & $\mathrm{H}_{3}$ & $\begin{array}{l}\text { It is more likely that excessive exposure to political } \\
\text { advertisements leaves a significant impact on the voting } \\
\text { behavior of voters. }\end{array}$ & $X$ & $\checkmark$ \\
\hline
\end{tabular}

$\mathbf{H}_{\mathbf{1}}=$ It is more likely that respondents gain more political knowledge about political parties through political advertising. Imperial results reveal that this hypothesis was proved from the statistical test. Second

$\mathbf{H}_{\mathbf{2}}=\quad$ "It is more likely that social media is more popular than electronics media for political advertising among respondents" this hypothesis was also proved from a statistical test.

$\mathbf{H}_{\mathbf{3}}=\quad$ It is more likely that excessive exposure to political advertisements leaves a significant impact on the voting behavior of voters.

Table 3. Political advertisement exposure to voters during general elections of 2018 through Electronic Media and Social Media

\begin{tabular}{|c|c|c|c|c|c|c|c|c|}
\hline \multirow{7}{*}{$\begin{array}{l}\text { Impact } \\
\text { Advertising }\end{array}$} & \multirow{6}{*}{ Political } & $\begin{array}{l}\text { Frequency } \\
1=\text { Low } \\
5=\text { High }\end{array}$ & $\begin{array}{l}\text { Not } \\
\text { at all }\end{array}$ & $\begin{array}{l}\text { Strongly } \\
\text { disagree }\end{array}$ & Disagree & Agree & $\begin{array}{l}\text { Strongly } \\
\text { agree }\end{array}$ & Total \\
\hline & & 1 & 4 & 5 & 7 & 6 & 3 & 25 \\
\hline & & 2 & 2 & 6 & 11 & 8 & 6 & 33 \\
\hline & & 3 & 6 & 7 & 9 & 12 & 11 & 45 \\
\hline & & 4 & 3 & 16 & 11 & 6 & 8 & 44 \\
\hline & & 5 & 5 & 21 & 12 & 9 & 6 & 53 \\
\hline & & Total & 14 & 49 & 52 & 42 & 43 & 200 \\
\hline ** Correlatio & s significa & It at 0.05 leve & & & & $1=200$ & & \\
\hline
\end{tabular}

Above mention, the table shows the comparative analysis of the results of exposure to political advertising and the impact of political advertising on the behavior of voter choice. For this 
purpose, five response categories are selected to indicate respondents' choice toward political behavior table indicates that a higher amount of respondents disagrees with the notions that perceived a significant impact from political advertising on their party affiliation. The respondents did not agree that political advertisement is no way to change political affiliation. These results also show the results of all three political parties' political advertising which are being surveyed by the researcher. Although the response category of disagreeing and strongly disagree clear cut clarifies the theme in this research paper that political advertising of all three parties is not very focused and effective for the respondents of the Sargodha region. Hence respondents' loyalties and bradryhood affiliations play a very significant role in their political choices instead of political advertisement which portrayed through electronic media and social media during the election of 2018.

\section{Conclusion}

Political scholars and communications experts agree that appeals used in political rhetoric play an effective role in political communication and voter's intention. During the election phase of 2018, all leading political parties used social media and electronic media for the pursuance of the election campaign to attract voters and youth. In this regard, all leading political parties produce their political ads in the shape of audio, video, and print. These political advertisements played a very significant role in the mobilization of a political campaign. The majority of political advertisements of all parties included their future policies and manifestoes in their advertisement to attract target audiences. This political advertisement somehow changed the political loyalties in some areas of the Sargodha region. Political slogans and political campaigns are also used in the general elections of 2018 in Pakistan. Also, this research work concludes that political advertisement plays a very useful and significant role in the participation and mobilization of political campaigns. The results reveal that political advertisement enhances the political knowledge of voters and this leads to mobilization of political campaigns. Furthermore, the political advertisement makes an association between political knowledge and voting behavior of voters during the phase of the general election of 2018. It is also observed that in the Sargodha region voters and not very much impressed by political advertisement by political parties because they are having strong affiliation through their baradryhood. So it is highly suggested that in the general elections of 2018 there was no strong attachment between voters' voting behavior and political advertisement.

\section{References}

Ansell, A. (2013). Race and ethnicity: The key concepts. Routledge.

Bucy, E. P., \& Gregson, K. S. (2001). Media participation: A legitimizing mechanism of mass democracy. New media \& society, 3(3), 357-380.

Burton, M., Miller, W. J., \& Shea, D. M. (2015). Campaign craft: the strategies, tactics, and art of political campaign management: The strategies, tactics, and art of political campaign management. ABC-CLIO.

Calmore, J. O. (2000). Race-Conscious Voting Rights and the New Demography in a Multiracing America. NCL Rev., 79, 1253.

Dalton, R. J., \& Wattenberg, M. P. (1993). The not so simple act of voting. Political science: The state of discipline II, 193-218.

Davies, P. J., \& Newman, B. I. (2006). Winning elections with political marketing. Psychology Press.

Gates Jr, H. L., Griffin, A. P., Lively, D. E., Strossen, N., \& Post, R. C. (1996). Speaking of race, speaking of sex: Hate speech, civil rights, and civil liberties. NYU Press.

Highfield, T. (2017). Social media and everyday politics. John Wiley \& Sons.

Jhally, S. (2014). The codes of advertising: Fetishism and the political economy of meaning in consumer society. Routledge.

Johnson-Cartee, K. S., Johnson-Cartee, K. S., \& Copeland, G. (1997). Inside political campaigns: Theory and practice. Greenwood Publishing Group.

Marcus, G. E., Neuman, W. R., \& MacKuen, M. (2000). Affective intelligence and political judgment. University of Chicago Press.

Margolis, M., Resnick, D., \& Resnick, D. M. (2000). Politics as usual (Vol. 6). Sage.

McEnteer, J. (2006). Shooting the truth: The rise of American political documentaries. Greenwood Publishing Group.

Munir, I. (2011). Social movements, religion, democracy, and political communication in Pakistan (Doctoral dissertation, Communication, Art \& Technology: School of Communication). 
Nimmo, D. D., \& Combs, J. E. (1992). The political pundits. Greenwood Publishing Group.

Sabato, L. (1980). Gubernatorial Politics and New Campaign Technology. State Government, 53(3), 148-152.

Seidman, S. A. (2008). Posters, propaganda, and persuasion in election campaigns around the world and through history. Peter Lang.

Spicer, C. (2013). Organizational public relations: A political perspective. Routledge.

Stieglitz, S., \& Dang-Xuan, L. (2013). Social media and political communication: a social media analytics framework. Social network analysis and mining, 3(4), 1277-1291.

Sundquist, J. L. (2011). Dynamics of the party system: Alignment and realignment of political parties in the United States. Brookings Institution Press.

Valenzuela, S., Arriagada, A., \& Scherman, A. (2012). The social media basis of youth protest behavior: The case of Chile. Journal of communication, 62(2), 299-314.

Wilson, J. Q. (1995). Political organizations (Vol. 46). Princeton University Press.

Zahid, M. (2017). Effects of Political News Consumption and Discussion on Political Behavior During Election Campaign 2013 Pakistan (Doctoral dissertation, University of the Punjab, Lahore). 